\title{
Anti-Sex Trafficking Movement of Bangladesh and the TheORIES OF Transnational Social Movements
}

\author{
Afroza Anwary \\ Minnesota State University, Mankato
}

Using reports, interview data, and participant observation, this research examines the anti-sex trafficking movement in Bangladesh, analyzing the effects of internationalization and the growth of regional and transnational efforts to curb sex trafficking in women and children. This research examines the ability of activists of two organizations of Bangladesh to shift their engagement among national, regional, and transnational levels to take advantage provided by complex internationalism and examines the connection between current wave globalization and sex-trafficking. Results indicate that international institutions and transnational coalitions played an important role in shaping the regional networks of activists within South Asia which fostered the development of a larger regional anti-sex-trafficking movement. Results also indicate that much of the soft and hard laws growing up around sex trafficking are the results of actions by South Asian governments, international forums, and NGO activism and not exclusively by northern intervention.

Scholarly research on transnational social movements (TSMs) often perceives the present wave of TSMs as a result of globalization and the development of transnational civil society across national boundaries. Scholars assume three processes that link TSMs and

Direct correspondence to Afroza Anwary, Department of Sociology and Corrections, 113 Armstrong Hall, Minnesota State University, Mankato, MN 56001 (afroza.anwary@mnsu.edu). The author wishes to thank two anonymous reviewers for their thoughtful suggestions as well as the editor for her editorial guidance. 
national social movements: diffusion, externalization, and domestication (defined below). This view precipitated the development of concepts, such as the "boomerang effect," defined as a condition "where non-state actors, faced with repression and blockage at home, seek out state and non-state allies in the international arena, and in some cases are able to bring pressure to bear from above on their government to carry out domestic political change" (Sikkink 2005:154). So, for example, when the domestic political arena of the global South becomes irresponsive to the concerns of weak domestic groups, these groups, finding no recourse within domestic political space, search out transnational connections and inform stronger activists of the global North of their concerns. Northern activists influence northern state and non-state actors to pressure southern governments. This view has contributed to an over-generalized view of the role of activists of the South as reaching out to the activists of the North for external sponsorship for a boomerang effect.

Tarrow (2005) argues that the relationship between globalization and transnational activism has been conflated. He argues that "internationalism" and the process of "internationalization" are important concepts to understand the origins and mechanisms of transnational activism. Internationalism refers to the structure through which globalization is mediated. Internationalization generates vertical and horizontal relations between state and non-state actors at sub-national, national, and supranational levels. These relations create networks of formal and informal institutions. These institutions provide domestic actors with opportunities to encounter people with similar experiences and "form coalitions that transcend their borders" (25).

While globalization creates possibilities for "rooted" activists by processing their interests, grievances, and oppression, it may not explain how, when, and why these activists engage in TSMs. Internationalism offers a place for people's grievances, anger, and interests to be articulated. Tarrow (2005) argues that "rooted cosmopolitans," not transnational activists, are the sources of TSMs. They are rooted in face-to-face local networks and are concerned with local conditions. Rooted activists have bases outside the target states and societies. They negotiate the very real constraints 
of the local and international spaces and take advantage provided by the process of "complex internationalism," defined as "the expansion of international institutions, international regimes, and the transfer of the resources of local and national actors to the international stage, producing threats, opportunities and resources for international NGOs, transnational social movements and, indirectly, grassroots social movements" (Tarrow and della Porta 2005:235).

This essay uses Tarrow's framework of TSMs to analyze the anti-sex trafficking movement of Bangladesh. Specifically, it examines whether the activists of two organizations are able to shift their engagements among national, regional, and transnational levels to take advantages provided by the complex internationalism. In addition, it examines the ability of the activists of the South to build coalitions with the activists of the North on the commonalities of their claims. It also examines the ability of the activists of the South to build regional coalitions within the South by which they can successfully challenge their target.

Trafficking in women and children across national borders for sexual services is a multi-billion dollar industry. According to the United Nations (UN), 1.2 million children are trafficked and forced into the sex industry every year (UNICEF 2005a). The majority of these women and children come from poor countries such as Bangladesh. The Bangladesh National Women Lawyers' Association (BNWLA) estimates 300,000 Bangladeshi trafficked children work as prostitutes in India's brothels (BNWLA 1997). An estimated 10,000-20,000 Bangladeshi young women and girls are trafficked annually to other parts of South Asia and the Middle East for sexual exploitation, involuntary servitude, and debt bondage (The New Age 2004). Research shows 27 percent of girls rescued from traffickers were 13 to 16 , and 55 percent were 17 to 24 years-old (Ain O Shalish Kendra 2000).

Trafficking in women and children for sex is gender specific. Both men and women are abducted and trafficked for selling their organs and/or to provide bonded labor, but the majority of those trafficked for sexual purposes are young women and girls (Kolakovic, Martens, and Long 2002). 
In the early 1980s, Bangladeshi women's organizations organized attempts to stop the trafficking of Bangladeshi women and children. Activists identified negative impacts of globalization on women and children of Bangladesh and had laid the groundwork for transnational action against trafficking developed in the mid1990s. Pressure from international agencies, networks of Bangladeshi women's organizations, and regional organizations of South Asia made the Bangladeshi government promulgate and implement several laws against trafficking in women and children.

\section{Theoretical Frame}

Scholarly research on transnational social movements (TSMs) identifies how globalization and transnational coalitions provide threats and opportunities to national social movements by diffusing movement ideas transnationally and by the mobilization of weak national groups that target international institutions (Tarrow and McAdam 2005). Keck and Sikkink (1998) demonstrate the ways in which transnational connections between activist groups can facilitate dramatic changes in places that seem to be otherwise removed from globalization. The contemporary changing structure of international politics provides national activists with new opportunities to develop transnational coalitions, new strategies, and expanded resources (Tarrow 2005). Taken together, scholars assume three processes that link TSMs and national social movements: diffusion, externalization, and domestication.

According to della Porta and Tarrow (2005:2), challengers of one country can effectively pressure their government to ratify international norms in domestic space in three different ways: 1) by diffusion, which is defined as "the spread of ideas, practices, and frames from one country to another"; 2) by externalization, which is defined as "the challenge to supranational institutions to intervene in domestic problems or conflicts"; and 3) by domestication, which is defined as "the playing out on domestic territory of conflicts that have their origin externally."

Tarrow (2005) adds four more processes to the above three: global framing, scale shifting, coalition forming, and internaliza- 
tion. Internalization and global framing are close to domestication in that the rooted cosmopolitans use global framing in domestic struggle. Scale shifting represents attempts of activists to move claims from local to national to transnational levels and vice versa. Coalition forming refers to the projection of claims to international institutions and groups with common claims.

National movements emerge independently in various countries with indigenous mobilization which then attract TSMs with similar goals. Alternatively, activists of national movements who have difficulty establishing legitimacy at home turn to international arenas, networks, and actors to achieve their goals at the national level (Keck and Sikkink 1998; Tarrow 2005).

Conflicting goals, ideas, and interests among various groups across borders are barriers to developing a collective identity in TSMs and may divide groups (Rupp and Taylor 1999). To transcend their differences and unite groups across borders, activists of TSMs campaign to develop common goals and mobilize actions against similar targets. Activists of TSMs have important role in the development of new forms of action and new ways of framing domestic issues (Tarrow 2005). The major benefits of coalitions and networks are information exchanges and enhancement of lobbying abilities (Khagram, Riker, and Sikkink 2002). Social movements, Nongovernment organizations (NGOs), transnational coalitions, labor movements, and international institutions are important actors of international contentious politics (Tarrow 2005). They pose threats and opportunities to the dynamics of TSMs. Sikkink (2005) identifies the shifting nature of the international opportunity structure, the dynamic nature of multilevel governance, and their changing relationships to variation across issues, regions, and time.

Tarrow (2005) casts doubt on globalization as a source of TSMs and locates TSMs squarely in local movements and demonstrates that transnational contention, although is possible, is not easy. While it is true that globalization has spawned grievances, people engage in transnational activism through the process of internationalization as defined above. In addition, Tarrow questions the over-generalized role of transnational visionaries in TSMs. He argues that rooted cosmopolitans are the source of TSMs. 
Rooted cosmopolitans are connected to locally rooted networks structured around global issues. They are able to shift their engagement among local, national, and supranational levels and are able to take advantage provided by complex internationalism. Although they are able to "shift their activities among levels, taking advantage of the expanded nodes of opportunity of a complex international society" (Tarrow 2005:43), it is their local conditions that ultimately shape their approaches to international opportunities. Therefore, rooted cosmopolitans must work to sustain public interests in local issues that they advocate. They also have to work hard to garner support from their transnational allies whose interests may be only loosely connected to their own interests. Only externalization and coalition forming, mentioned above, provide possibilities for sustained domestic-international connections. The other four processes are embedded in local contexts and provide only temporary connections between local and international activism.

The bulk of empirical studies that draw out the theoretical implications of the dynamics of TSMs are based on Europe and the Americas. Not too many TSMs researchers have taken seriously vibrant domestic social movements of nonwestern societies of the global South that are connected to global advocacy networks of the North. As a result, the connections between TSMs of the South and the North are wrongly considered as vertical, and activists of the South are perceived as reaching out to the activists of the North for external sponsorship for a boomerang effect. This research ignores the ability of the activists of the South to build regional coalitions within the South by which they can successfully challenge their target. Thus, the agency of the rooted cosmopolitans of the South is ignored by TSMs researchers of the North.

An analysis of domestic social movements of a non-western society, such as Bangladesh and their connections to TSMs and regional social movements, may cast new light on the theories of TSMs. Toward this end, I add a case to the literature of the dynamics of TSMs through an examination of the anti-sex trafficking movement in Bangladesh. I examine opportunities and challenges 
provided by international institutions and events for transnational activities around which activists of the anti-trafficking movement of Bangladesh organize themselves.

I focus on coalition-building efforts of the "rooted" activists of Bangladesh based on their common claims with the activists of other parts of South Asia and with activists of the North. I argue that transnational coalitions provide the southern activists with the opportunity to frame the plight of trafficked women and children in terms of human rights' violations. Alternatively, ideological differences in transnational coalitions often divide the coalitions leading the southern activists to network regionally. I demonstrate how the activists of Bangladesh are able to shift their engagements among national, regional, and transnational levels and are able to take advantage provided by complex internationalism. Finally, I examine the effectiveness of the anti-sex trafficking movement of Bangladesh in terms of law enactment. I see law as providing a clear visibility of the activists to transform their grievances into general issues. Law signals that the government recognizes that trafficked women and children's human rights are at stake and the realization that activists can do something to protect this general issue without paying a high cost.

In the beginning of this paper, I critically examine the connection between the current wave of globalization and sex trafficking in Bangladeshi women and girls. Then, I ask two questions related to transnational, regional, and national mobilization. First, how do different scales of activism, such as national, regional, and global, interact with one another with regard to the trafficking in Bangladesh that seems so localized at first blush? Second, do international, regional, and national activist groups have a certain synergy with one another - that the networks between them may or may not produce important changes in policies related to trafficking in women and girls of Bangladesh? These are important questions and an angle that not too many gender scholars have taken when explaining TSMs. Last, I discuss the development of laws against sex trafficking in Bangladesh.

This essay draws on documents and reports of NGOs and international organizations involved in the anti-sex trafficking 
movement. Documents included posters, flyers, brochures, newsletters, letters written by one activist/government official to another, minutes of meetings of movement organizations, and letters to the editors of newspapers. Documents were collected from organizational archives.

The data drawn on in this article were gathered at multiple time periods between 1994 and 2005 in selected towns and metropolitan areas of Bangladesh and India. In-depth non-structured interviews of some activists of Bangladesh who most centrally are involved in the anti-sex trafficking movement provided me with first-hand accounts of their interactions with the local, regional and global advocacy groups. I used snowball sampling to build a pool of activists. I also interviewed fifty men and women who regularly participated in anti-trafficking activities. The questions were open-ended. The length of the interviews varied from two to four hours. In addition to formal interviews, throughout the course of my field research, I informally interviewed the respondents in seminars, meetings, and entertainments organized by different organizations.

Participant-observation method was used to collect information on the dynamics of national and regional scales of activism. As a covert observer, I attended cross-border seminars, meetings, workshops, rallies, demonstrations, and social gatherings organized by women's organizations and international institutions involved in the anti-human trafficking movement. In addition, I collected newspaper articles on sex trafficking from three newspapers of Bangladesh: The Daily Ittefaq, The Daily Star, and The New Age.

Trafficking in women and children in Bangladesh is varied. However, increased rates of trafficking in recent years are closely related to globalization. In this sense, the Bangladesh anti-trafficking movement of women and children in the sex industry is a form of, using Tarrow's (2005:19) words, "a counter-movement against neo-liberalism in the form of global justice movement." The following section focuses on the role of globalization in sex trafficking in women and young girls of Bangladesh. 


\section{Globalization and Sex Trafficking}

Researchers indicate that economic survival is the key to understand human trafficking (Sassen 2000; Bertone 2004). In Bangladesh, economic collapse and rapid decline in the agricultural sector, contributed by neo-liberal Structural Adjustment Policies (SAP), resulted in greater rates of unemployment and increased poverty. In their research, Khondker and Raihan (2004) and Mujeri (2002) assessed the adversarial effects of economic reforms introduced in the late 1980s and early 1990s on the economy of Bangladesh. They demonstrate that there is an important shift in the structure of economy "as the share of agricultural [Gross Domestic Product] declined to around 26 percent by 2000 from 33 percent in 1980" (Khondker and Raihan 2004:10). They argue that the economic reform led to welfare loss for Bangladeshi households and an increase in poverty rates in both rural and urban sectors.

SAP has led to the destruction of domestic industries and biodiversity-based production that contributes to increased rates of poverty (Combat 2002) in this predominantly rural society of Bangladesh. Empirical research on trafficking in Bangladesh (Shamim 2001; Ali 1997; Resistance 1997) demonstrated how SAP is responsible for sex trafficking in women and young girls. In 2003, export-oriented Bangladesh garment factories employed 1.5 million workers: 90 percent women. Women in garment factories constituted 70 percent of total employment in the manufacturing sector in Bangladesh in 2003. The majority of those women were "young, ... and rural migrants mostly ignorant [of] urban life situation[s]. ... and constitute[d] a high risk group for being the victims of violence" (Mahtab 2003:29) and victims of traffickers.

The Harkin Bill against Child Labor implemented in Bangladesh in the mid-1990s also contributed to increased juvenilization of poverty as thousands of children lost jobs in export-oriented garment factories and became vulnerable to trafficking (The New Age 2004). In July 2004, the US State Department listed Bangladesh among the top ten countries most vulnerable for trafficking and accused the government of Bangladesh for taking no action against human trafficking. The United States warned that if the trafficking 
situation did not improve by the end of 2004, Bangladesh was going to face sanctions on non-humanitarian and non-trade sectors from the United States. Sanctions, without solving poverty, contributed to increased rates of child sex trafficking (The New Age 2004).

Shrinking economic opportunities cause men to generate income by trafficking in women and children. Those men develop close links with transport companies, border police, immigration authorities, and courts to help transport their victims, causing a rapid increase in the number of organizations and enterprises involved in trafficking in women, especially in the border areas of India and Bangladesh (UBINIG 1997).

The destruction of domestic industries, biodiversity-based production, declining economic opportunities for male breadwinners in traditional sectors of the rural economy, and the inability of the government to provide social services have increased the burdens on women to support households. Many men from poor rural communities migrate to the cities and abroad to find work, leaving or abandoning their wives and children in villages where they have no exchangeable resources in the formal sector of the labor market. Unskilled and semi-skilled desperate women who head households are encouraged to take any job opportunities abroad or within the country to avoid starvation at home. This has caused the "feminization of migration" (Kempadoo and Doezema 1998).

Feminization of international migration caused by globalization of economy, poverty, and social displacement is responsible for increased rates of sex trafficking in Bangladesh. Activists have rescued Bangladeshi trafficked women and children from brothels of India, abandoned by their husbands and fathers who were not able to support them. Victims were tempted to migrate to India by traffickers who promised them high standards of living, food, and steady jobs. Traffickers took advantage of their vulnerable situations (Ali 1997).

The intensification of transnational and trans-local networks, the development of modern communication technologies, and information flow in a globalized world are responsible for increased rates of sex trafficking. Many activists mentioned that present-day traffickers are not similar to petty pimps of the past. They are in- 
volved in organized crime and have knowledge of sophisticated information technology. They have access to computers that help them exchange information with various institutional networks of cross-border money flow. According to Vasudev (2003:10), "[It] is now an organized crime with international gangs involved, some with underworld links. Earlier touts used PCOS to make calls and chloroform-laced handkerchiefs to make the girls unconscious. Now they carry mobile phones, video cameras and mood altering depressant drugs. Dayawati, 15, rescued in Mewat in Haryana was found carrying a strip of tranquilizers which she said were pills for energy given to her by her 'chacha.'. . . Cultured, English-speaking voices picked up phones, when numbers given by rescued girls were called by India Today."

Permeable borders and differences of bilateral and multilateral agreements among governments about repatriation and rescue account for some of the trafficking (UBINIG 1997).

In summary, poverty, shrinking economic opportunities, globalization, feminization of survival, the vulnerability of women due to lack of education, and permeable national borders are responsible for trafficking in women and children in Bangladesh. The majority of the above factors are connected to the underlying forces, such as neo-liberal economic policies. That produces a weak state and an economy dependent on foreign investments. Such an economy is incapable of sustaining rural and domestic industries and food security, and that contributes to sex trafficking in women and children across national borders.

Many women's advocacy NGOs of Bangladesh have been instrumental in raising public awareness about violations of human rights of trafficked women and children. In the next section I explain how two women's NGOs of Bangladesh in close partnership with international institutions address sex trafficking in women and children by framing sex trafficking as a form of violence against women and children. These two organizations are the Bangladesh National Women Lawyers' Association (BNWLA) and Unnayan Bikalper Niti Nirdharoni Gobeshana (UBINIG), or Policy Research for Development Alternatives. Both have networks with grass-roots organizations and transnational advocacy NGOs structured around 
women's rights (BNWLA 1998; Shamim 2001). Both organizations are rooted at the national level, although they often participate in regional and transnational campaigns, lobbying activities, and protest events.

\section{National Scale of Activism}

Organized and collective responses to stop trafficking in women and children were instigated by women's organizations, such as BNWLA and UBINIG in the early 1980s. BNWLA is a national, voluntary, women-lawyers' organization that works to build resistance to violence against women. Formed in 1979, it implemented anti-trafficking projects in 1991 (BNWLA 1998). BNWLA is affiliated with many national and international human rights' organizations (BNWLA 2001).

The United States Agency of International Development (USAID) and the Canadian Development Agency (CDA) provide major funding for anti-trafficking projects of BNWLA (BNWLA 1998). Members interact with the government, NGOs, and international agencies. Programs and activities of BNWLA include lobbying, advocacy, and monitoring state interventions to combat violence against women in general. BNWLA also operates shelter homes for women and children rescued from traffickers (BNWLA 2002).

UBINIG is a community-based activist organization working on women's issues. Numerous women's rights advocacy groups formed this umbrella organization responsible for coordinating various aspects of the women's movement of Bangladesh. Formed in 1984, it is affiliated with several Bangladeshi grass-roots organizations. Through person-to-person contact, the staffs of UBINIG try to raise public awareness of trafficking (UBING 1997). It consults government officials to plan strategies to combat trafficking and helps draft national legislation to stop trafficking and sexual abuse of women and children. UBINIG has built links among many women's rights advocacy groups of Bangladesh and South Asia.

The initial call of the activists in the 1980s to combat sex trafficking in women as a gendered form of violence did not produce the same outrage in the people of Bangladesh as did other types of 
violence against women, such as dowry death and acid attack. The government considered sex trafficking as an immoral act. Discussion about sex and sexuality was taboo. Women trafficked into the sex industry were perceived as "fallen women." Sexual activity was perceived as a private matter.

In 1992, activists demonstrated that a large number of the rescued trafficked victims were young girls who needed government protection (UBINIG 1997). Activists successfully framed the plight of trafficked girls as unjust by which the media was sensitized. In the early 1990s, newspapers published stories of sexual and physical violence that victims of sex trafficking endured in brothels across borders (The Daily Ittefaq, January 1992-December 1992). In order to sensitize the public, activists documented that, in most cases, trafficked girls and women were powerless and isolated from their communities and were victims of violations of their fundamental rights (Ali 1997; UBINIG 1995). By providing data on trafficked victims, they identified the severity of the problem to convince the public that sex trafficking was a problem that needed attention. In public meetings, activists argued that participation in collective action was the only way to force the government to develop and implement policies against trafficking.

Examples from BNWLA and UBINIG activities illustrate that anti-trafficking activism of Bangladesh in the 1980s successfully laid the groundwork for transnational and South Asian regional action that developed in the 1990s. Until the end of 1993 when activists demanded that the government develop laws against sex trafficking, the government was not responsive to their demands. Activists argued that sex trafficking in women and girls occurs across national borders. Therefore, their claims to stop trafficking should not be limited to Bangladesh but connect to advocacy networks of South Asian Association of Regional Cooperation (SAARC) countries that make similar claims about sex trafficking (BNWLA 1998). Attempts of BNWLA, UBINIG and other similar organizations to combat sex trafficking in South Asia drew on their pre-existing social ties with women's organizations and human rights' organizations of India, Pakistan, and Nepal that addressed oppression of women in previous events. 
Funding from donor agencies such as the United Nations (UN) and USAID was the key to BNWLA and UBINIG to participate in regional and global conferences on women's rights and research on trafficking in women and children (BNWLA 1998). In collaboration with different international agencies around the world, the UN sponsors a series of regional conferences in South Asia to address trafficking in women and children that builds coalitions between Bangladeshi women's NGOs and South Asian NGOs combating trafficking, which I address below.

\section{Regional Scale of Activism}

This section examines the process by which the anti-sex trafficking activists of Bangladesh "externalize" (della Porta and Tarrow 2005) their claims to stop sex trafficking at the South Asia regional level. It examines how they "form coalitions" (Tarrow 2005) and challenge regional institutions such as SAARC governments, to intervene in domestic problems of sex trafficking in Bangladesh. It illuminates how rooted activists of Bangladesh shifted the scales of their activism and their claims to stop trafficking from national to regional levels and vice versa.

The effort of Bangladeshi activists to build regional coalitions to stop sex trafficking started in the mid-1990s during the SAARC Summit meetings that discussed the role of women in economic development and the need to protect children. The SAARC Summit of 1993 accorded the highest priority to child survival, girl-child protection, and economic development. The pre-conference meetings of the 1995 SAARC Summit on social, political, and economic issues were keys to forming a coalition of NGO networks of Bangladesh and South Asia (BNWLA 1998; The New Age 2004). These conferences brought activists of South Asia together and provided them opportunities to articulate the issues of violence against women and children and trafficking in women and children, especially the need to protect the human rights' abuses of girl children (UBINIG 1995; BNWLA 1998).

Participation in conferences helped the activists of South Asia to identify common regional threats related to poverty and traffick- 
ing and structured the common political opportunities available in different national contexts of South Asia. The approach of Indian and Nepalese activists - combating trafficking to poverty reduction by involving women as vital human resources in economic development - made effective contributions to the understanding of Bangladeshi activists combating human trafficking (BNWLA 1997).

Based on the South Asia regional meeting in 1994, activists of Bangladesh developed Dhaka Resolution upholding women's rights in all spheres of society and sent the resolution to the SAARC ministerial meeting on women held on July 29-30, 1994, in Bangladesh. Sex trafficking in women and children was defined as "the most barbaric form of violence" against women and children (UBINIG 1995). Activists documented trafficking in women and children across borders and the violence those women and children experienced. They urged the SAARC Summit to acknowledge trafficking in women and children as a major problem in the region.

In regional preparatory meetings preceding the 1995 Beijing World Congress of Women, women's groups included a separate theme of violence against women and children to be discussed in 1995 at the Beijing World Congress of Women. NGO delegates from seven South Asian countries participated in the regional meeting in Bangladesh in December 1994 and developed a South Asian Platform for Action. The Platform clearly specified that the growth in trafficking in women had hindered the development of women and the country (UBINIG 1995). The Platform claimed that government should be accountable for sex trafficking.

The 1995 SAARC Summit declaration mentioned the sexual abuse threat an orphaned girl-child faced, but failed to develop a Platform for Action. Therefore, the activists decided to "externalize" their claims by "forming coalitions" with international groups and organizations that would participated in the upcoming 1995 World Congress of Women. They wanted to convince those international organizations to intervene in sex trafficking in South Asia (discussed below). In addition, activists felt the need to develop a more organized regional women's human rights' movement to direct protests against SAARC governments (Resistance 1997). 
Two regional NGOs of South Asia were formed in the mid1990s: Resistance Network (Resistance) and SAARC People's Forum (Forum). Forum and Resistance, among many other national and regional organizations, provided the activists of Bangladesh an opportunity to shift their engagements in anti-sex trafficking activities from national to regional levels.

Resistance was formed in October 1996 in a workshop organized by UBINIG. Various women's and human rights groups of Bangladesh, Nepal, India, Pakistan, and Sri Lanka established links through this network (Akhter 1996). To promote the implementation of women's rights as human rights, UBINIG's mandate expanded with the formation of Resistance, which monitors whether national governments of South Asia keep promises made at international conferences.

SAARC, formed in 1985, promotes economic, social, cultural, and technical aspects in seven South Asian nations (SAARC 2007). SAARC nations organize periodic meetings and hold summits - involving heads-of-states - followed by declarations on promoting socio-economic, cultural, and technical aspects of SAARC nations. SAARC offers an opportunity within which domestic movements against sex trafficking, NGOs, and regional coalitions against sex trafficking claim justice for human rights of women and children vulnerable for sex trafficking.

Formed in 1998, Forum is a coalition of organizations of South Asian nations involved in socio-economic development. Resistance had the leading role in initiating Forum. Gradually, other regional networks of organizations were involved in Forum (UBINIG 2003). Forum's core group involves different government ministries, NGOs, international NGOs, and UN agencies and plays a catalytic role by regularly reviewing critical areas of concerns related to women's human rights and development.

Members of Resistance and Forum share information on legal and policy developments by governments. They lobby governments and create regional pressures on the governments. They take actions at the SAARC level to sensitize the governments to combat trafficking. By organizing regional and sub-regional conferences, participating in numerous regional events, and conscientiously 
following-up numerous platforms, Resistance and Forum achieve goals of regional conferences (Akhter and Shimu 2001).

In 1996, the Asian Women's Human Rights Council (AWHRC) collaborated with Resistance and OXFAM (Nepal) to pressure governments. At the 1997 SAARC Summit, they demanded that governments develop policies against trafficking. On December 20, 1996, AWHRC met with seven ministers of SAARC countries during the SAARC Council of Ministers meeting in India. The Council demanded that SAARC governments prioritize combating trafficking in the SAARC Heads of State meeting held in May 1997.

The Pre-conference meetings preceding the 1997 SAARC Summit allowed regional NGOs to articulate the absence of bilateral and multi-lateral agreements among South Asian governments about repatriation and the rescue trafficked victims. Regional and national NGOs closely cooperated with each other to strategize their actions to pressure governments to act against trafficking. BNWLA and UBINIG urged the government of Bangladesh to improve migration management and the dissemination of safe migration messages and demanded that the involvement of government in migration management would help the prevention of trafficking (UBINIG 1995; BNWLA 1997). They demanded that the government implement the Beijing Platform For Action (PFA).

To implement the PFA, the government and NGOs of Bangladesh drafted a National Plan of Action (NAP) in February 1997. The NAP was drafted following the definition of violence against women included in the PFA. On March 1997 a National Policy on Women was introduced. According to the policy, the government is committed to stop trafficking of women and rehabilitate trafficked women (Baseline 2005).

In April 1997, the AWHRC - in collaboration with OXFAM Nepal and Resistance - organized a roundtable on trafficking in South Asia in Nepal and developed a set of recommendations to combat trafficking. In the SAARC Summit in May 1997, a delegation named South Asian Activists representing the AWHRC, Resistance, and OXFAM (Nepal) met with the prime ministers of Bangladesh, Nepal, Pakistan, and India and presented a set of recommendations to combat trafficking. 
On May 13, 1997, SAARC leaders unanimously agreed to take measures against trafficking within SAARC countries. The 1997 SAARC Summit declaration stated the possibility of a Regional Convention on Combating the Crime of Trafficking in Women and Children for Prostitution should be examined by the relevant technical committee (SAARC 2004). After the 1997 SAARC Summit, Action against Trafficking and Sexual Exploitation of Children-Bangladesh (ATSEC-Bangladesh) developed an Action Plan to combat sexual exploitation of children and sex trafficking. It submitted a draft - Convention of Child and Women Trafficking - to the Prime Minister of Bangladesh.

In July 1998, Forum organized a workshop in New Delhi titled, "Trafficking in South Asia: A Conceptual Clarity Workshop." Activists and representatives of governments of South Asia exchanged ideas about the governments' initiatives to stop trafficking. Participants of the conference demonstrated links between lack of education, food security, migration, and trafficking in women and children (UBINIG 2003) and recommended solutions to the governments. South Asian regional NGO networks submitted a draft convention to the $10^{\text {th }}$ SAARC Summit held in Sri Lanka in 1998 where the first Forum conference was held.

The 1998 SAARC Summit introduced a draft in July called the convention for Prevention and Combating Trafficking in Women and Children. The convention was severely criticized by many NGOs - such as Resistance and Forum - and UN agencies. They argued that the Convention was strictly concerned with trafficking for prostitution and ignored other purposes for trafficking. Critics also argued that the convention did not distinguish women who consent to sex work from women and children who are forced to work in the sex industry. In August 1999, in a workshop organized by Resistance, a new convention of trafficking was suggested. According to this convention, "Trafficking in women (and children) consists of all acts involved in the procurement, transportation, forced movement, and/or selling and buying of women (and children) within and/or across border by fraudulent means, deception, coercion, direct and/or indirect threats, abuse of authority, for the purpose of placing a women (and a child) against her (and his/her) 
will without her (and his/her) consent in exploitative and abusive situations such as forced prostitution (commercial sexual abuse), forced marriage. Bonded and forced labour, begging, (camel jockeying and other sports), organ trade, etc." (ICDDR, B 2006:2).

The second Forum conference in Nepal in 2000 made two major demands: to stop trafficking in women and children and to ensure food security (UBINIG 2003). The 2000 SAARC Convention for Combating Trafficking in Women and Children for Prostitution recommended that SAARC countries form Regional Task Forces to facilitate and implement measures to prevent and interdict trafficking in women and children, set bilateral and multi-lateral mechanisms of employment agencies, and promote awareness about trafficking (Marium 2004).

Women's groups and human rights' organizations of Bangladesh, in close cooperation with many regional women's organizations of South Asia, campaigned for the public to pressure governments to develop and enforce laws related to violence against women and trafficking in women and children (UBINIG 1997). In 2001, BNWLA organized 29 workshops and dialogue meetings (BNWLA 2001). ATSEC participated in the cross-border Regional Workshop in Nepal in 2001, organized by the National Network against Girl Trafficking (ATSEC 2001). In September 2001, Forum organized a national consultation meeting in Dhaka that provided representatives of government agencies, NGOs, activists, lawyers, and women's organizations opportunities to share their experiences and their recommendations to combat trafficking. By the end of 2001, documentation of trafficking in women and children by activists and protests by citizens in the city were followed by demands for better anti-trafficking efforts. Women's groups pursued UNICEF-Bangladesh to encourage cross-border cooperation by governments of South Asia to stop trafficking children into the sex trade. UNICEF focused its efforts on the prevention of trafficking of children and the protection, recovery, and reintegration of trafficked victims (UNICEF 2002), discussed below.

In November 2001 participants of the conference-South Asia Consultation for Second World Congress against Commercial Sexual Exploitation of Children — developed the South Asia Strat- 
egy (Strategy) to combat trafficking, emphasizing the need to set up international and regional mechanisms to monitor the progress in the fight against trafficking and child sexual exploitation. Strategy suggested ways to work more effectively to stop trafficking and commercial sexual exploitation and emphasized free and compulsory primary education, second-chance learning as a way to improve girls' status, and the reduction of gender discrimination (ECPAT 2001). According to Strategy, all South Asian countries were to develop a National Plan of Action that clearly identified a timeline for action and defined effective monitoring programs. Strategy especially emphasized child trafficking, recognized treating all girls and boys under 18 as children, and urged South Asian governments to sign and ratify Optional Protocol on the Sale of Children, Child Prostitution, and Child Pornography (Optional Protocol) introduced by UNICEF in October 2001 (BNWLA 2001). A core group was formed, and they developed a National Plan of Action against sexual trafficking and prepared a background paper (BNWLA 2001). In 2001, the Bangladesh government was one of the first ten countries to ratify the Optional protocol and translate it into national law.

BNWLA organized 468 discussion meetings in Bangladesh between November 2002 and November 2005 (BNWLA 2005). Bangladesh TV broadcast discussions of workshops, roundtables, and responses of the SAARC Summit to anti-trafficking efforts. Newspapers indicated violence against women and trafficking in women and children skyrocketed in the late 1990s (UBINIG 2003). These efforts conveyed the trafficking issue to the public and increased public sensitivity to the news.

In summary, regional institution such as SAARC had generated ties among rooted activists of South Asia at regional levels. These ties have created formal institutions at the regional level, such as Forum and Resistance. Regional organizations provided rooted activists of Bangladesh and other parts of South Asia a place to articulate their concerns for human rights' abuses of trafficked victims. Those organizations were able to shift the scales of activism from the national to the regional level and vice versa. They successfully challenged regional institutions such as SAARC governments to intervene in domestic problems of sex trafficking in Bangladesh. 


\section{Transnational Scale of Activism}

This section examines whether anti-sex trafficking activists of Bangladesh work at the transnational level exclusively. Specifically, it analyzes the role of international institutions and international conferences in providing activists of Bangladesh with the ability to shift their activities from national to transnational levels and vice versa. It examines whether the activists of Bangladesh require northern intervention to take action against sex trafficking.

The efforts of Bangladeshi activists to build transnational coalitions to stop sex trafficking started in 1994. Activists mentioned that the failure of the 1995 SAARC Summit to develop a Platform for Action to combat sex trafficking and the upcoming 1995 Beijing conference provided the site for the activists to articulate claims on the state to stop trafficking through international frameworks. The South Asia Platform for Action, discussed above, developed by the delegates from seven South Asia countries at the regional preparatory meeting preceding 1995 Beijing Conference in Bangladesh, was presented at the Beijing Congress. BNWLA, UBINIG, Resistance, and Forum prepared pamphlets to raise awareness about trafficking in Bangladesh. They distributed pamphlets to official delegates at the 1995 Beijing Conference and to activists attending the NGO Forum '95 in China (UBINIG 1995).

In another workshop organized by the NGO Forum in China on August 31, 1995, Asian participants discussed and reviewed NGO activities and government policies and programs about eliminating trafficking in women and children in Asia. Trafficking survivors shared their ordeals (UBINIG 1997). Participants argued that trafficking for sex should be addressed in the wider context of migrant women who willingly travel across national borders. The 1995 Fourth World Conference framed the question of trafficking in women as a form of violence against women and a matter of pressing international concern. According to the Platform for Action (PFA) developed in the conference, forced marriage and labor were considered forms of trafficking (United Nations 1995). Many activists of Bangladesh came into direct contact with activists of global women's rights' movements at the 1995 Beijing confer- 
ence. This contact helped them forge a new ideology that linked multi-issues such as sex trafficking, migration, and forced labor. In the process, they broadened their support networks operating on national, regional, and international levels.

By following the 1995 Beijing Conference, activists combating trafficking defined trafficking as a form of abuse of women's and children's human rights (BNWLA 1998). Although activists focused on sex trafficking, they reflected broader perspectives: educational and employment opportunities for women and children, violence against women and children, trafficking in women and children for sexual oppression and other forced labor, and global social justice. The Beijing conference helped activists to develop a new strategy (i.e., global social justice). The new strategy helped them to mobilize support at the national, regional, and international levels. Activists successfully weaved together the national concerns of sex trafficking and the need for global social justice for women.

The government of Bangladesh endorsed the PFA developed in Beijing and committed its implementation at the national level. However, the government routinely failed to prosecute any traffickers. The government also failed to implement laws against forced marriage and labor. UBINIG, BNWLA, Resistance, and Forum monitored the actual practices of the states concerning to commitments to combat trafficking made at the Beijing conference to reassert the responsibilities of the governments (Resistance 1997).

Activists of Bangladesh participated in a workshop on August 31, 1995, on the Elimination of Trafficking in Women in Asia, organized by the International Movement Against All Forms of Discrimination and Racism (IMADR) in China. Speakers of India addressed the trafficking of young girls for child prostitution. Korean speakers identified the increased rates of sex trafficking, which is related to rapid industrialization of Korea and an increase in the child prostitution in Asia. An Indian speaker pleaded to workshop participants, "Please help our daughters" (UBINIG 1995:34). In another workshop at NGO Forum 1995, two young Nepalese survivors of trafficking spoke of their ordeals in Indian brothels. They stressed the importance of empowering women and girls by 
educating them and by providing vocational training to help them escape trafficking and prostitution (UBINIG 1995).

A declaration was adopted at the end of IMADR workshop that reflected a consensus of the participants: "Changing in the economic and cultural structures is needed for the radical solution of the problem. This would include remedying the widening gap between the rich and poor, the discriminatory consumption pattern in the countries of the North, the media, and tourism" (UBINIG 1995:35).

In 1996, UNICEF organized the First World Congress against Commercial Sexual Exploitation of Children in Sweden. It gave the attending 122 government officials and NGOs - including officials and NGOs of Bangladesh - an opportunity to review the effectiveness of legal instruments as follow-up processes. They developed an Agenda of Action and asked governments to specify measures, aims, and time frames in which to reduce the numbers of sexually exploited children. UNICEF made international human rights' laws and conventions accessible to women's organizations and human rights' organizations of South Asia to combat trafficking.

In the late1990s, international donor agencies such as USAID, International Centre for Diarrhoeal Dieses Research, Bangladesh, (ICDDR, B), and the British Council provided financial support to local, national, regional, and international NGOs working on poverty reduction programs and women's empowerment for research and publications, for nationwide awareness campaign, to assess impacts of trafficking on the victims and the society, and to rescue and repatriate trafficked victims. Agencies also helped to develop national, regional, and international networks to share information and experiences and to develop national and regional policies against human trafficking (ICDDR, B 2006). As a result, several major national, regional, and international anti-trafficking networks were formed. For example, ATSEC was formed. ATSEC chapters in Bangladesh, Nepal, and India played a central role in supporting the networks. Networks establish contacts and facilitate linkage among individuals, organizations, and agencies working to stop human trafficking for sexual exploitation. ATSEC Bangladesh is connected to four hundred grassroots level NGOs of Bangladesh 
(The Daily Star 2002) and many transnational networks of organizations combating trafficking. The growing numbers of regional and international NGO networks help to organize coordinated campaigns and facilitate advocacy and social mobilization.

In October 2001, UNICEF introduced the Optional Protocol on the Sale of Children, Child Prostitution, and Child Pornography. UNICEF urged governments to ratify the treaty, implement the standards of the Optional Protocol, and translate the protocol into national law criminalizing those who violate children's rights. The anti-sex trafficking activists of Bangladesh took to the streets. They demanded that the Bangladesh government ratify the Optional Protocol. The Bangladesh government was one of the first ten countries to ratify the Optional Protocol and translate it into national law.

The 2001 South Asia Strategy was submitted to the Second World Congress against Commercial Sexual Exploitation of Children in Japan in December 2001. More than 3,000 representatives of governments and several networks of NGOs participated in the congress and reviewed the South Asia Strategy. Through roundtable discussions, debates, and presentations, the congress concluded that the magnitude of sex trafficking in children was increasing. Speakers emphasized the urgency of the enlargement of partnerships and networks to combat trafficking (UNICEF 2001). As a result, the NGO Support Group was formed and linked key NGOs of South Asia and international NGOs combating sex trafficking with the UN and its partners.

In 2002, the UN introduced the Protocol to Prevent, Suppress, and Punish Trafficking in Persons, Especially Women and Children, which supplemented the UN Convention against Transnational Organized Crime and entered into force in 2003 (UNICEF 2005b). The 2002 Protocol introduced the first definition of international trafficking in persons. The UN called for South Asian governments to ratify the Protocol and develop specific measures to prevent human trafficking, prosecute traffickers, and protect victims. The UN assisted seven South Asian countries in signing two regional Conventions, one of which was the Convention on Preventing and Combating Trafficking in Women and Children for Prostitution. In 2004, five countries ratified the convention: Bangladesh, Bhutan, 
India, Maldives, and Pakistan. Those countries also ratified the Convention on Regional Arrangement for the Promotion of Child Welfare in South Asia (ECPAT International 2004). While governments extended interstate cooperation for rescue and rehabilitation of victims of trafficking, Bangladesh newspapers documented continued sex trafficking across borders (The Daily Star, January 2002-December 2004).

As anti-trafficking mobilization continued in Bangladesh, eight governments of South Asia, UN agencies, NGOs, and children and youth met in Sri Lanka in late 2004 to examine the progress in South Asia since the commitment made at the 2001 Second World Congress against Commercial Sexual Exploitation of Children in Japan. Participants agreed that, while governments took some actions against trafficking, more action was needed. Participants emphasized cooperation between the governments and NGOs, UN agencies, and multi-lateral partners for effective implementation of policies to stop trafficking (UNICEF 2005c). Bangladeshi activists demanded reforms of discriminatory laws depriving women and children of their human rights and that ratification of the international treaty be enacted into domestic legislation by the National Parliament (ECPAT International 2004). The Bangladesh government responded by introducing laws against trafficking. The government developed specific programs to protect, rescue, and reintegrate trafficked victims. The following section explains different statutes of the Bangladesh government to combat trafficking.

In sum, the activists of the anti-sex trafficking movement projected their claims to safeguard the human rights of trafficked victims to international institutions such as the UN that have similar claims. The link with international institutions and conferences has contributed to the formation of loosely connected transnational coalitions. This link also helped to strengthen the existing coalitions among various types of actors operating on national, regional, and transnational levels.

The growing numbers of national networks and regional networks of South Asia were much more effective in coordinating sustained campaigns nationally and regionally than sustained global campaigns against sex trafficking, which I briefly discuss below. 


\section{Points of Convergence and Points of Divergence of Southern and Northern Activists}

All activists mentioned that they never worked exclusively at the transnational level. Their participation in global conferences and symposiums was infrequent. The majority of the activists mentioned that they were members of several human rights' movements that had different goals than the goals of the anti-sex trafficking movement. The goals of these movements were nationally based. For example, an activist mentioned that she was involved in combating the mistreatment of refugees by the police in refugee camps, (those from Burma living in Bangladesh). She was required to be in Bangladesh during the First World Congress against Commercial Sexual Exploitation of Children in Sweden in 1996. She had wanted to address human rights' violations of these victims at the conference. Although she had the means to travel to Sweden, she stayed in Bangladesh to work with international humanitarian agencies in Bangladesh to create safe spaces for the Burmese refugees in Bangladesh.

Many organizations that were involved in the anti-sex trafficking movement had goals in addition to the goal to combat sex trafficking. For example, the goals of the BNWLA were to act as a pressure group to review and reform national laws, mobilize women lawyers of the country, act as a platform for enhancing the professional status of women, provide services for uplifting the status of women and children, and combat sex trafficking. These goals required the members of the BNWLA to work in the country. Although a few members felt that they needed to move their claims to stop sex trafficking from national to regional and transnational levels by participating in regional and transnational conferences, they were involved in different kinds of activities in Bangladesh. They were also concerned with local conditions that often challenged their abilities to move claims from national to transnational levels and vice versa.

The majority of activists, who were solely involved in the anti-sex trafficking movement, often worked in Bangladesh. They offered shelter homes to trafficked victims, rescued women who 
were trafficked within Bangladesh, and lobbied government to enforce the existing regulations prohibiting trafficking.

Many activists were raising families and needed to be home. Others were involved in full-time work and failed to get time off to participate in global conferences. Only a few activists were somewhat successful in negotiating the very real constraints of international spaces.

Those activists who participated in global conferences in North and in South Asia argued that addressing sex trafficking was easier at the South Asia region among the SAARC countries where it was easier to network with NGOs across borders than addressing the issue at a much broader global level (BNWLA 2001; SAARCFUW 2001). They argued that financial support of the United Nations and other international agencies to attend global conferences was not common. It was difficult to fulfill bureaucratic requirements of these institutions to get their financial support. Some activists suggested that difficult immigration and customs' regulations of countries of the North made it difficult for activists of the South to participate in global conferences that occurred in the North. Increasing complexities related to travel arrangements and the difficulties of obtaining visas for travel between the countries of the South and the North became much more difficult, especially after the September 11, 2001, terrorist attack on the United States. Many activists mentioned that they did not have enough money to travel to distant countries of the North to participate in global conferences. Activists emphasized the need to take advantage of regular SAARC meetings in South Asia to engage in collective action.

Some activists also revealed a major division between many activists of South Asia and activists of the North. Many activists of South Asia considered sex trafficking in women and girls as a form of oppression and argued for abolition of all prostitution across national borders. They demanded that governments provide educational and economic opportunities to women and young girls vulnerable for trafficking. In addition, they demanded the safe return of trafficked victims to their countries of origin. Many activists of the North argued for the rights of sex workers who crossed borders. They argued that trafficked women who willingly sell sex in 
an international, informal labor market must be viewed as women following an alternative strategy of survival. They documented how immigration policies and their enforcement have increased the vulnerability to abuse of many undocumented trafficked women by immigration and law enforcement agencies. They argued that the criminalization of all trafficked women would lead to their deportation for illegally crossing borders to work.

Connection with the activists of the North had a deep influence on activists of South Asia combating trafficking. Many forged a new ideology which linked them and the activists of the North. They reframed trafficked women who willingly crossed national borders to sell sex as women's rights to self-determination. They distinguished between victims of forced trafficking and voluntary migration, ensuring voluntary repatriation, and demanded that governments must stop all forced trafficking. Thus, they broadened their support network. Other activists saw an enormous division between them and the activists of the North who demanded the rights of sex workers to cross national borders. These activists of the South did not see the division as reconcilable. They decided to engage in collective action with those within South Asia.

In sum, this research suggests that activists of South Asia were somewhat successful in building coalitions with the activists of the North on the commonalities of their claims to stop forced trafficking in women and children. However, these coalitions were not sustained. Activists were more successful in building sustained regional coalitions within South Asia than the activists of the North. Regional coalitions, inter-government institutions, and "rooted cosmopolitans" (Tarrow 2005) helped the anti-sex trafficking movement of Bangladesh to challenge the government of Bangladesh. The government responded to these challenges by introducing anti-sex trafficking laws, which I discuss below.

\section{Laws and Combating Trafficking in Bangladesh}

In the mid-1990s, pressure from international agencies, national and regional women's groups, and human rights' organizations to stop sex trafficking in women and children made the government of 
Bangladesh promulgate several laws. The 1995 Cruelty to Women and Children (Special Provisions) Act prescribes death or life imprisonment for trafficking in women and children for any purpose. The government also ratified the Convention on the Elimination of All Forms of Discrimination against Women, Convention for the Suppression of Traffic in Persons and Exploitation of the Prostitution of Others, the Copenhagen Declaration, and the Beijing Platform of Action. To stop child trafficking, the government also enacted the 1996 Women and Children Repression (Special Provisions) Act, which permits capital punishment for offenders.

The government formed divisional courts to deal quickly with trafficking and to develop further laws to punish traffickers. The government also introduced the Suppression of Violence against Women and Children Act (2000) (SVWCA) after a series of dialogues between the government, human rights' organizations, and women's organizations. Harsh penalties were prescribed for traffickers of women and children. Section 6 of the act addressed trafficking of girls under 18 for sexual purpose and stated, "If anyone exports, imports, buys or sells a child or keeps a child for those purposes, then he or she is subject to death penalty or life imprisonment" (Marium 2004:20). Section 7 addressed trafficking of women for sexual abuse (the SVWCA does not define sexual abuse). Trafficking in women was given priority; trafficking in children was treated as complementary. The processes dealt similarly with two separate issues: one for women and the other for children.

The Women and Children Repression Prevention Act 2000 (WCRPA), introduced and amended in 2003, stated in Section $5(2)$, "When a woman is sold for hire or otherwise disposed of to prostitute [she] would be punished with death sentence or life [in prison] ... and ... liable to fine" (BNWLA 2001). Sections 5 and 6 dealt with punishments for child trafficking across borders and buying and selling children for any immoral and unlawful purpose. The sections stated that violators would receive death sentences or rigorous life imprisonments, as well as fines.

Bangladesh ratified the International Labor Organization Convention on the Worst Forms of Child Labor No. 182 in 2001, which stated the government must protect children from working 
conditions that damage their physical and psychological well-being. The government also publicized anti-trafficking efforts in the media. The Ministry of Women and Children Affairs introduced a Coordinated Program to Combat Child Trafficking in Bangladesh. A similar project was introduced by the Ministry of Home Affairs (Ain O Shalish Kendra 2000), and a ministerial-level committee was developed to address trafficking.

The Child Development Coordinated Program to Combat Child Trafficking, developed by the Bangladesh government (active at the national, district, and local levels), supports organizations that rescue, repatriate, and rehabilitate victims of trafficking. The government also organizes seminars, workshops, and rallies to raise trafficking awareness and encourage public discussions on alternatives to prostitution. A National Plan of Action for Children 1997-2002 adapted by the government addresses the need to stop child trafficking and the commercial sexual exploitation of children. The plan states that the government wants to stop intra- and inter-country trafficking in children and wants to help the victims of sexual exploitation.

\section{Conclusion}

The research on the anti-sex trafficking movement of Bangladesh indicates that the coordination of regional and transnational organizations and the anti-sex trafficking activists of Bangladesh to gain access to the UN helped the development of linkage among the national movement, the regional movement, and transnational human rights' organizations. However, as Tarrow (2005) indicates, joint and sustained transnational mobilization was difficult to make happen. Although activists of Bangladesh were able to shift their activities among national, regional, and transnational levels by taking advantage of opportunities provided by a complex international society, their local conditions ultimately shaped their approaches to international opportunities. They worked hard to garner support from their transnational allies of the North by "externalizing their claims" (Tarrow 2005) and by "forming coalitions" (Tarrow 2005) whose interests were only loosely connected to their own 
interests. This research suggests that a cross-national mobilization occurred between the Bangladeshi anti-sex trafficking movement and the anti-sex trafficking movement of other parts of South Asia much faster than mobilization between the Bangladeshi anti-sex trafficking movement and transnational women's human rights' movements. Ideological differences in transnational coalitions and local conditions of the activists of Bangladesh were major barriers to coalitions between the activists of the North and South.

Results presented in this article point to an important gap in the literature of TSMS. Given the importance of coalitions of regional activists' networks in the success of the anti-sex trafficking movement of Bangladesh, many TSM scholars still do not fully understand the important role of the regional coalitions. Results also indicate that much of the soft and hard laws growing up around sex trafficking are the results of actions by South Asian governments, international forums, and NGO activism and not exclusively by northern intervention.

\section{References}

Ain O Shalish, Kendra. 2000. Human Rights in Bangladesh, 1999. Dhaka, Bangladesh: Ain O Shalish Kendra.

Akhter, Farida. 1996. South Asian Workshop on Trafficking in Women and Children: Formulating Strategies of Resistance. Dhaka, Bangladesh: UBINIG.

Bangladesh: Narigrantha Probartana Press.

Ali, Salma. 1997. Survey in the Area of Child and Women Trafficking. Dhaka, Bangladesh: Bangladesh National Women's Lawyers Association.

ATSEC. 2001. "From the Coordinator's Desk." Newsletter July. Retrieved July 29, 2007 (http://atsec.tripod.com/atsecbangladeshchapter/id9. html).

Baseline Report. 2005. Facilitating the Fulfillment of State Obligations toward Women's Equality. Kuala Lumpur: International Women's Rights Action Watch Asia Pacific.

Bertone, Andrea Marie. 2004. "Sexual Trafficking in Women: International Political Economy and the Politics of Sex." Pp. 466-71 in Kaleidoscope of Gender: Prisms, Patterns, and Possibilities, edited by Joan Spade and Catherine Valentine. Belmont, CA: Wadsworth. 
BNWLA. 1997. Survey in the Area of Child and Women Trafficking. Dhaka, Bangladesh: Bangladesh National Women Lawyers' Association.

—. 1998. Special Bulletin. Dhaka, Bangladesh: Bangladesh National Women Lawyers' Association.

- 2001. Sexual Exploitation of Children in Bangladesh. Dhaka, Bangladesh: Bangladesh National Women Lawyers' Association.

—. 2002. Violence against Women in Bangladesh 2002. Dhaka, Bangladesh: Bangladesh National Women Lawyers' Association.

—. 2005. Background of Anti-trafficking Movement of BNWLA. Dhaka, Bangladesh: Bangladesh National Women Lawyers' Association.

Combat. 2002. Trafficking in Women and Children. Dhaka, Bangladesh: Center for Women and Children Studies.

della Porta, Donatella and Sidney Tarrow. 2005. "Transnational Process and Social Activism: An Introduction." Pp. 1-20 in Transnational Protest and Global Activism: People, Passion, and Power, edited by Donatella della Porta and Sidney Tarrow. New York: Rowman \& Littlefield Publisher.

ECPAT. 2001. "South Asia Strategy against Commercial Sexual Exploitation of Children and Child Sexual Abuse." Retrieved July 29, 2007 (http://www.ecpat.net/eng/A4A02/03_online/ENG/A4A/Appendices_6_South_Asia_Strategy.pdf) .

ECPAT International. 2004. Report on Laws and Legal Procedures Concerning the Commercial Sexual Exploitation of Children in Bangladesh. Bangkok, Thailand: ECPAT International and Plan International Inc.

ICDDR, B. 2006. "Trafficking of Women and Children in Bangladesh: An Overview." Retrieved June 6, 2006 (www.icddrb.org).

Keck, Margaret and Kathryn Sikkink. 1998. Activists beyond Border: Advocacy Networks in International Politics. Ithaca, N.Y.: Cornell University Press.

Kempadoo, Kamala and Jo Doezema. 1998. Global Sex Workers: Rights, Resistance and Redefinition. London, England: Routledge.

Khagram, Sanjeev, James Riker, and Katherine Sikkink. 2002. "From Santiago to Seattle: Transnational Advocacy Groups Restructuring World Politics." Pp. 3-23 in Restructuring World Politics: Transnational Social Movements, Networks, and Norms, edited by Sanjeev Khagram, James Riker, and Katherine Sikkink Minnesota: University of Minnesota.

Khondker, Bazlul H. and Selim Raihan. 2004. 'Welfare and Poverty Impacts of Policy Reforms in Bangladesh: A general Equilibrium 
Approach." Presented at the Northwest Universities Development Consortium Conference, October, 1-3, Montreal, Canada.

Kolakovic, Peter, Jonathan Martens and Lynellyn Long. 2002. "Managing Irregular Migration through Bosnia and Harzegovina." Pp. 235-45 in New Challenge for Migration Policy in Central and Eastern Europe, edited by Frank Laczko, Irene Stacher, and Amanda Klekowski von Koppenfels. Geneva, Switzerland: International Organization for Migration.

Mahtab, Nazmunnessa. 2003. "Female Garment Workers: Economic and Social Security." Pp. 19-34 in Role of NGO in Effective Implementation of PFA and CEDAW in Bangladesh, edited by Salma Khan. Dhaka, Bangladesh: NGO Coalition on Beijing Plus Five: Women for Women.

Marium. Lubna. 2004. Children Cry Alone. Dhaka, Bangladesh: Ain O Shalish Kendra.

Mujeri, M.K. 2002. "Bangladesh: External Sector Performance and Recent Issues." Bangladesh Institute of Development Studies, Dhaka, Bangladesh. Unpublished Manuscript.

Resistance. 1997. Trafficking in Women and Children in South Asia. Dhaka, Bangladesh: Narigrantha Probartana Press.

Rupp, Leila and Verta Taylor. 1999. "Forging Feminist Identity in an International Movement: A Collective Identity Approach to Feminism." Signs: Journal of Women in Culture and Society 24:363-86.

SAARC. 2004. "Important Events. 2004." Retrieved July 29, 2007 (http:// www.jang.com.pk/important_events/saarc_2004/dec_9th.html).

SAARC. 2007. "South Asian Association for Regional Cooperation." Retrieved July 29, 2007 (http://www.saarc-sec.org/main.php).

SAARCFUW. 2001. Seminar on Trafficking of Women and Children in SAARC Countries. Dhaka, Bangladesh: South Asian Association of Regional Cooperation Federation of University Women.

Sassen, Saskia. 2000. "Women's Burden: Counter-geographic of Globalization and the Feminization of Survival." Journal of International Affairs 53(2): 503-24.

Shamim, Ishrat. 2001. Mapping of Missing, Kidnapped and Trafficked Children and Women: Bangladesh Perspective. Dhaka, Bangladesh: International Organization for Migration.

Sikkink, Katherine. 2005. "Patterns of Dynamic Multilevel Governance and the Insider Outsider Coalition." Pp. 151-74 in Transnational Protest \& Global Activism: People, Passions, and Power, edited by Donatella della Porta and Sidney Tarrow. New York: Rowman and Littelefield. 
Tarrow, Sidney. 2005. The New Transnational Activism. New York: Cambridge University Press. and Doug McAdam. 2005. "Scale shift in Transnational Contention." Pp. 121-47 in Transnational Protest \& Global Activism: People, Passions, and Power, edited by Donatella della Porta and Sidney Tarrow. New York: Rowman and Littelefield. and Donatella della Porta. 2005. "Conclusion: Globalization, Complex Internationalism, and Transnational Contention.” Pp. 227-47 in Transnational Protest \& Global Activism: People, Passions, and Power, edited by Donatella della Porta and Sidney Tarrow. New York: Rowman and Littelefield.

The Daily Star. 2002. "Trafficking Prevention Campaign Package Launched," The Daily Star, November 22, p.8.

The New Age. 2004. "US Threat of Sanction against Bangladesh: The Case of Trafficking in People." 2004. The New Age, October 14, p. 8.

UBINIG. 1995. Trafficking in Women and Children: The Case of Bangladesh. Dhaka, Bangladesh: Narigrantha Probartana Press.

—. 1997. Fact Finding Missions on Trafficking in Women and Children from Bangladesh to India and Pakistan. Dhaka, Bangladesh: Narigrantha Probartana Press.

—. 2003. Brochure, July 2003. Dhaka, Bangladesh: Narigrantha Probartana Press.

United Nations. 1995. "Traffic in Women and Girls. 1995. General Assembly Resolution. 50/167." Retrieved January 1, 2006 (http://www1. umn.edu/humanrts/resolutions/50/167GA 1995.html).

UNICEF. 2001. "Second World Congress against Commercial Sexual Exploitation of Children." Retrieved July 29, 2007 (http://www. unicef.org/events/yokohama/bangkok-final-report.html).

- 2002. "How UNICEF is Working to Curb the Sexual Exploitation of Children." Retrieved November 15, 2002 (http://www.unicef. org/sexualexploitation).

—. 2005a. "Child Trafficking." Retrieved July 29, 2007 (http://www. unicef.org/protection/index_exploitation.html).

- 2005b. "UNICEF Applauds U.S. Ratification of Trafficking Protocol." Retrieved December 10, 2005 (.

_. 2005c. "Children in South Asia Deserve Better Protection from Sex Abusers and Traffickers." Retrieved December 10, 2005 (http://www. unicef.org/media).

Vasudev, Shefali. 2003. "Girls for Sale." India Today, October 2003, pp. 10-16. 